\title{
Pengolahan Limbah Tahu dan Potensinya
}

\section{(Tofu Waste Treatment and Its Potential)}

\section{Mutiara Regita Cahyani, Intan Ayu Zuhaela, Teguh Endah Saraswati*, Sentot Budi Rahardjo, Edi Pramono, Sayekti Wahyuningsih, Witri Wahyu Lestari, Dian Maruto Widjonarko}

\author{
Program Studi Kimia, FMIPA, Universitas Sebelas Maret, J1. Ir. Sutami 36 A, Kentingan-Jebres \\ Surakarta, Jawa Tengah, Indonesia, 57126, (0271) 663375 \\ *Email: teguh@mipa.uns.ac.id
}

\begin{abstract}
Abstrak. Tahu merupakan produk makanan yang paling banyak dikonsumsi oleh masyarakat Indonesia. Produksi tahu di Indonesia masih banyak menggunakan metode konvensional dengan limbah yang dihasilkan belum dimanfaatkan secara optimal. Limbah tahu mengandung senyawa organik dengan $\mathrm{pH}$ yang rendah dan merupakan salah satu penyumbang polutan pada lingkungan perairan apabila tidak dilakukan proses pengolahan terlebih dahulu sebelum dibuang ke lingkungan. Pengolahan limbah tahu dapat dilakukan dengan beberapa metode, seperti penambahan bakteri mikroorganisme efektif, plasma ozonasi, biogas dan produksi makanan. Potensi pengolahan limbah tahu menjadi produk yang lebih bermanfaat belum banyak dikenal masyarakat luas. Oleh karena itu diperlukan metode alternatif pengolahan limbah tahu yang lebih efektif dan efisien sehingga mudah diterapkan pada masyarakat. Beberapa pengolahan limbah tahu berpotensi menjadi pupuk organik cair, mengurangi kadar polutan sehingga lebih aman jika dibuang ke lingkungan, yang selanjutnya dapat menghasilkan biogas sebagai bahan bakar alternatif. Selain itu, limbah tahu dapat digunakan untuk produksi makanan seperti Nata de soya, tempe gembus, dan keripik.
\end{abstract}

Kata kunci: biogas, limbah tahu, nata de soya, pupuk organik, tahu

Abstract. Tofu is a food product most consumed by Indonesians. Tofu production in Indonesia still uses conventional methods with the resulting waste which has not been used optimally. Tofu waste contains organic compounds with low $\mathrm{pH}$ and is a contributor to pollutants in the aquatic environment if it was not processed first before being discharged into the environment. Tofu waste treatment can be carried out by several methods, such as the addition of effective bacteria of microorganisms, plasma ozonation, biogas, and food production. The potential of tofu waste processing into a more useful product has not been widely recognized by the public. Therefore, it requires an alternative method of tofu waste treatment that is more effective and efficient so that it is easily applied to society. Some tofu waste treatment plants have the potential to become liquid organic fertilizer, reduce pollutant levels thus it is safer when released into the environment further used to produce biogas as an alternative fuel. In addition, it can be used for other food products such as Nata de soya,Ttempe gembus (a traditional fermented food), and chips.

Keywords: biogas, tofu waste, nata de soya, organic fertilizer, tofu

\section{Pendahuluan}

Tahu merupakan salah satu makanan khas Indonesia yang telah banyak dikonsumsi oleh masyarakat. Tahu memiliki asam amino paling lengkap yang memiliki daya cerna yang tinggi. Harga tahu yang relatif lebih murah menjadikan masyarakat cenderung memilih tahu sebagai santapan sehari-hari. Hal tersebut menyebabkan industri tahu mudah berkembang pesat dan berkembang di berbagai wilayah 
dengan menggunakan metode konvensional. Industri tahu pada setiap proses produksinya akan menghasilkan limbah tahu, yaitu berupa limbah tahu padat dan limbah tahu cair. Limbah padat berupa ampas yang berasal dari kacang kedelai, sedangkan limbah cair yang dihasilkan langsung dibuang ke sungai. Limbah padat tahu biasanya dimanfaatkan untuk pembuatan tempe gembus, kerupuk ampas tahu dan pakan ternak [1]. Limbah cair tahu mengandung protein, lemak, dan karbohidrat yang cukup tinggi, sehingga menyebabkan limbah cair tahu memiliki nilai BOD dan COD yang tinggi yaitu sebesar 5000$10000 \mathrm{mg} / \mathrm{L}$ dan 7000-10000 mg/L dengan $\mathrm{pH}$ rendah yaitu 4-5 [2]. Limbah cair yang langsung dibuang dapat mengakibatkan timbulnya dampak buruk pada lingkungan [3]. Pencemaran akibat limbah cair tahu menyebabkan lingkungan perairan menjadi kotor dan berbau, oleh karena itu diperlukan suatu upaya pengolahan limbah cair tahu sehingga ramah lingkungan. Limbah cair tahu dapat diolah menjadi produk olahan yang dapat mengurangi pencemaran lingkungan serta bermanfaat bagi masyarakat luas seperti biogas, pupuk organik cair, tempe gembus, nata de soya dan sebagai pakan ternak

\section{Hasil dan Pembahasan}

Tahu merupakan produk olahan yang berbahan baku kedelai [4]. Proses pengolahan tahu dalam produk akhirnya akan menghasilkan limbah padat dan limbah cair seperti ditunjukkan pada Gambar 1 . Limbah padat hasil olahan tahu berada dalam bentuk ampas tahu. Ampas tahu merupakan limbah padat yang dihasilkan saat proses pembuatan tahu. Pemanfaatan limbah padat tahu dapat digunakan sebagai bahan baku pembuatan kertas [5], tempe gembus, dan pakan ternak [6]. Limbah padat sudah banyak dikembangkan menjadi produk olahan seperti tempe gembus, keripik, pakan ternak [7]. Limbah cair tahu merupakan air limbah yang berasal dari buangan sisa proses penggumpalan tahu dan pencucian kedelai [8]. Limbah cair tahu memiliki tingkat pencemaran air yang lebih tinggi dibandingkan dengan limbah padat.

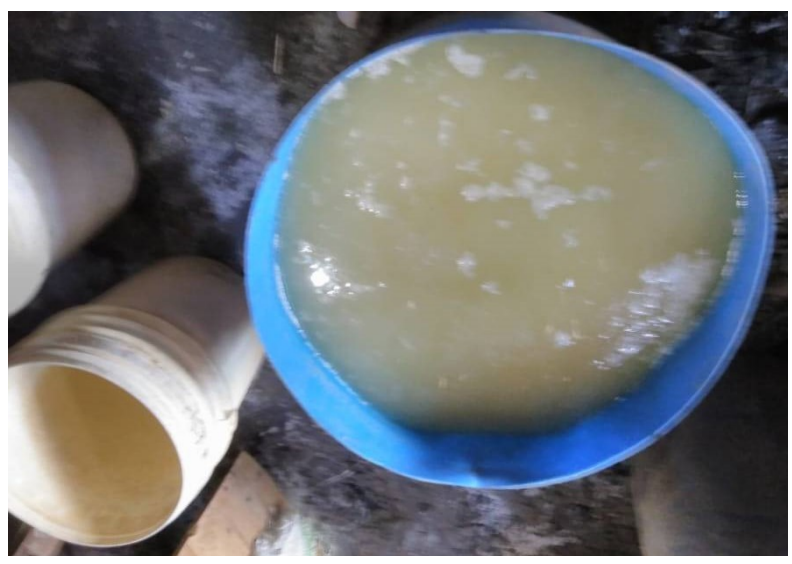

Gambar 1. Limbah Cair Hasil Pengolahan Tahu

Limbah cair dari tahu jika tidak diolah terlebih dahulu akan menimbulkan polusi di lingkungan terutama lingkungan perairan karena terkandung COD (Chemical Oxygen Demand) untuk mengetahui jumlah oksigen yang dibutuhkan untuk mengoksidasi zat-zat organik dalam limbah, BOD (Biological Oxygen Demand), TSS (Total Suspended Solid) untuk mendapatkan hasil residu padatan total dan $\mathrm{pH}$ dengan kadar tinggi seperti pada Tabel 1 [9]. Baku mutu air limbah cair industri pengolahan kedelai menurut Per.Men.LH. No. Kep-15/MENLH/2008 tentang Baku Mutu Limbah Cair bagi Kegiatan Industri, kandungan maksimum yang diperbolehkan untuk BOD, COD dan TSS berturut-turut adalah 150, 300 dan $200 \mathrm{mg} / \mathrm{L}$, hal ini berarti hasil analisis limbah cair tahu yang ditunjukkan pada Tabel 1 telah melampaui 
baku mutu yang dipersyaratkan. Sehingga diperlukan metode yang tepat dalam pengolahan limbah tahu untuk mengurangi resiko pencemaran lingkungan.

Tabel 1. Hasil Analisis Limbah Cair Tahu [9].

\begin{tabular}{ccc}
\hline Parameter & Satuan & Nilai \\
\hline COD & $\mathrm{mg} / \mathrm{L}$ & 29.700 \\
BOD & $\mathrm{mg} / \mathrm{L}$ & 8.852 \\
$\mathrm{TSS}$ & $\mathrm{mg} / \mathrm{L}$ & 936 \\
$\mathrm{pH}$ & - & 3,6 \\
\hline
\end{tabular}

Limbah cair tahu dihasilkan dari proses pencucian dan perebusan kedelai ditunjukkan pada Gambar 2. Limbah cair tahu mengandung zat organik $( \pm 70 \%)$ dan anorganik $( \pm 30 \%)$. Zat organik terdiri dari 1\% karbohidrat, $0,1-0,8 \%$ protein, $0,4-1,0 \%$ lemak, dan sekitar $0,4 \%$ mineral [10]. Kandungan zat organik yang tinggi apabila tidak dilakukan proses pengolahan akan berdampak buruk seperti polusi air, sumber penyakit dan bau tidak sedap. Potensi kandungan dari limbah cair tahu dapat dikembangkan menjadi berbagai produk yang lebih bermanfaat menggunakan teknologi biologi dan kimia. Metode kimia maupun biologi masing-masing memiliki kelebihan dan kekurangan. Metode kimia memerlukan bahan baku yang relatif mahal, namun proses pengolahan relatif lebih cepat dibandingkan dengan metode biologi.

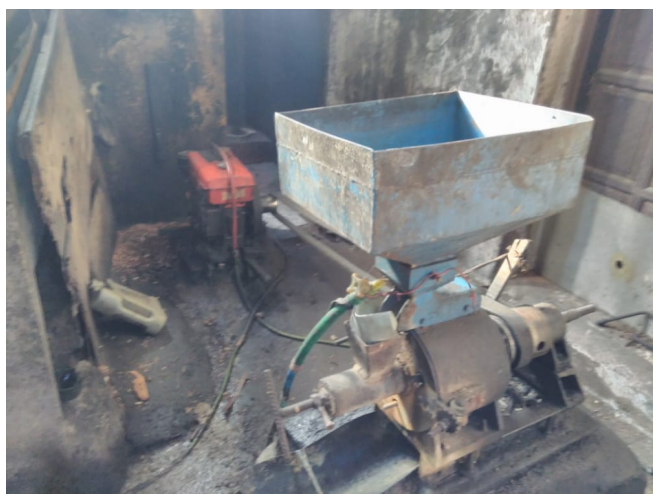

Gambar 2. Proses Pengolahan Tahu

Teknologi biologi untuk pengolahan limbah tahu seperti aerob, anaerob, kombinasi aerob-anaerob (Herlambang, 2002). Metode menggunakan sistem anaerob saat ini lebih banyak digunakan daripada aerob karena lebih ekonomis, mudah dioperasikan dan desain IPAL relatif mudah [11]. Limbah cair tahu dapat dimanfaatkan sebagai produk yang mempunyai nilai ekomonis tinggi dengan meggunakan sistem aerob yaitu Nata de Soya [12]. Pembuatan Nata de Soya melalui proses bioteknologi sederhana, yaitu dengan penambahan Acetobacter xylinum [13]. Nata de Soya adalah sebuah benda berwarna putih keruh, berbentuk padat, tipis dan kenyal seperti kolang kaling. Nata de Soya terbuat dari whey tahu yang telah mengalami proses fermentasi selama \pm 8 hari. Pembuatan Nata de Soya juga dapat menggunakan limbah cair tahu, karena dalam limbah cair tahu terkandung nutrient yang baik untuk pertumbuhan nata oleh bakteri [14]. Nata terbentuk oleh bakteri A. xylinum yang bersifat aerob pada limbah cair tahu, sehingga dapat terbentuk lapisan (nata) [15]. Nata adalah produk pangan berupa lapisan selulosa sebagai hasil 
fermentasi bakteri yang dapat dimakan. Bakteri A. xylinum membentuk nata pada media yang mengandung air, protein, lemak, karbohidrat dan mineral lain.

Mikroorganisme dalam sistem anaerob akan menguraikan senyawa organik dalam limbah cair dan menghasilkan hasil samping biogas [3]. Komponen biogas berupa gas $\mathrm{CH}_{4}$ 54-70\%; gas $\mathrm{CO}_{2} 27-45 \%$; gas $\mathrm{N}_{2} 3-5 \% ; \mathrm{H}_{2} 1 \%$; $\mathrm{CO} 0,1 \% ; \mathrm{O}_{2} 0,1 \%$ dan $\mathrm{H}_{2} \mathrm{~S}$. Gas metana $\left(\mathrm{CH}_{4}\right)$ merupakan komponen utama biogas yang memiliki energi kalor tinggi sekitar 4800-6700 kkal $/ \mathrm{m}^{3}$ sehingga dapat digunakan sebagai alternatif bahan bakar. Biogas dapat membangkitkan tenaga listrik sebesar 1,25 - 1,50 kilo watt hour (kwh) karena satu meter kubik biogas setara setengah liter bensin atau setengah liter minyak diesel [7]. Produksi biogas bergantung pada kinerja bakteri yang dipengaruhi oleh $\mathrm{pH}$, suhu, kandungan nutrient, waktu retensi dan reaktor yang digunakan ditunjukkan pada Gambar 3 [16].

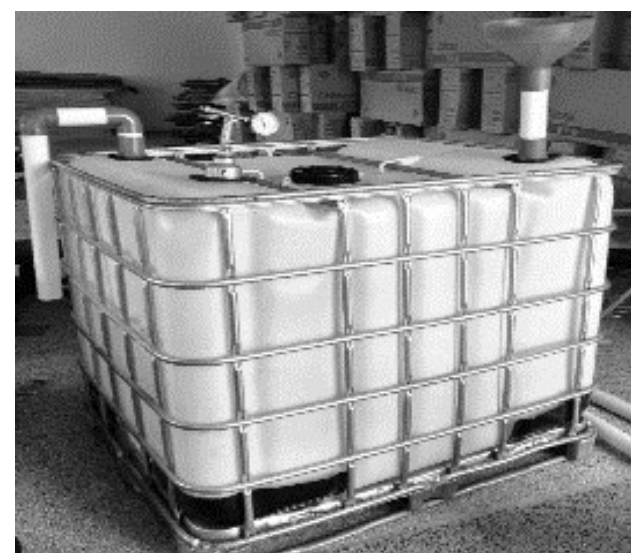

Gambar 3. Reaktor Biogas dari Limbah Cair Tahu [7]

Selain menjadi alternatif pembuatan biogas, sistem anaerob juga berpotensi dalam pembuatan pupuk organik cair, karena dalam limbah cair tahu mengandung bahan organik yang tinggi [17]. Pupuk organik cair berfungsi untuk menggemburkan permukaan lapisan tanah (top soil), meningkatkan populasi jasad renik, mempertinggi daya serap dan daya simpan air, sehingga dapat meningkatkan kesuburan tanah [18]. Penambahan pupuk organik pada tanaman dapat mendorong pembiakan jasad renik dan meningkatkan ketersediaan unsur hara tanaman [19]. Air limbah tahu dapat digunakan sebagai pupuk organik cair karena mengandung N, P dan K yang relatif cukup tinggi yaitu berturut-turut sebesar 43,37 $\mathrm{mg} / \mathrm{L}, 114,36 \mathrm{mg} / \mathrm{L}$ dan $223 \mathrm{mg}$ [20]. Limbah cair tahu dapat dijadikan alternatif baru yang digunakan sebagai pupuk organik karena limbah cair tahu mengandung berbagai nutrisi yang dibutuhkan oleh tanaman [21]. Pupuk organik cair yang berasal dari limbah tahu ditunjukkan pada Gambar 4.

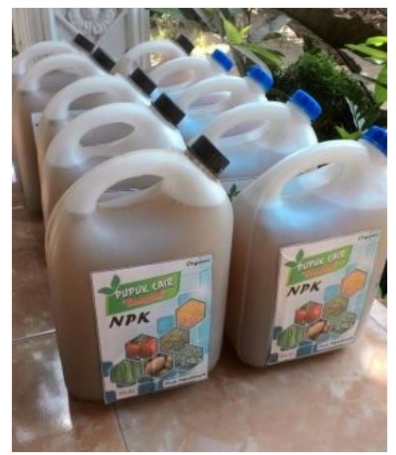

Gambar 4. Pupuk organik cair hasil pengolahan limbah cair tahu [22]. 
Teknologi kimia juga dapat digunakan dalam pengolahan limbah tahu seperti plasma ozonasi untuk mengurangi bau busuk, pengurangan kadar COD dan TSS. Plasma merupakan gas-gas yang terionisasi. Gas berupa udara bebas maupun oksigen ditambahkan yang ditambahkan energi atau panas menyebabkan atom melepaskan elektron sehingga akan membentuk plasma [23]. Penerapan teknik plasma pada disintegrasi polutan semakin dieksplorasi karena kompleksitasnya, variasi dan sifat oksidatif yang tinggi. Teknologi plasma mengandung spesies aktif radikal $\left(\mathrm{OH}, \mathrm{O}, \mathrm{H}, \mathrm{H}_{2} \mathrm{O}_{2}\right)$ yang mudah menguraikan senyawa organik dalam limbah tahu [24].

Disosiasi molekul oksigen pada plasma terjadi karena pengaruh dari elektron energi tinggi dalam celah antar elektroda sehingga menghasilkan ozon [25]. Ozon yang dihasilkan dari plasma bersifat oksidator kuat sehingga mampu menguraikan senyawa organik dalam limbah tahu dengan cepat, selain itu reaksi dekomposisi yang dipicu $\mathrm{O}_{3}$ akan menghasilkan radikal hidroksil. Radikal hidroksil ini berpotensi menghasilkan oksidasi yang lebih besar daripada $\mathrm{O}_{3}$ sehingga proses penguraian senyawa organik menjadi semakin cepat [26]. Proses plasma akan menghasilkan gas berbentuk gelembung-gelembung disekitar elektroda dalam reaktor plasma dalam limbah cair. Semakin banyak gelembung gas yang dihasilkan dalam reaktor plasma seperti pada Gambar 5, maka kandungan COD dan TSS dalam limbah cair tersebut juga akan berkurang [24].

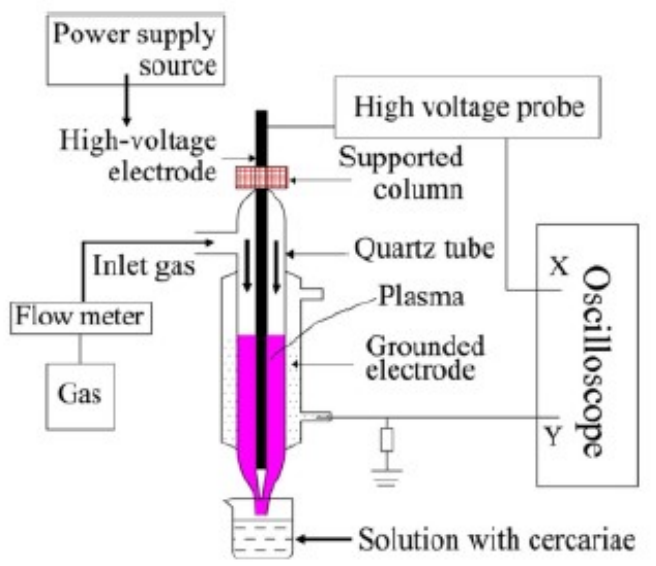

Gambar 5. Reaktor Plasma [27].

\section{Kesimpulan}

Limbah tahu terdiri dari padatan dan cair. Limbah tahu padat dapat langsung dimanfaatkan untuk pakan ternak maupun diolah menjadi makanan. Sedangkan limbah tahu cair dilakukan pengolahan menggunakan metode biologi maupun metode kimia. Berbagai teknologi pengolahan limbah tahu secara biologi maupun kimia perlu dikembangkan agar berpotensi memaksimalkan produk limbah tahu.

\section{Referensi}

[1] Hikmah S.F., Rahman A., Kholiq I.N. \& Andriani Z.Z.D., 2019, Teknologi Pengolahan Limbah Industri Tahu sebagai Upaya Pengembangan Usaha Kecil Menengah (UKM) di Kecamatan Gambiran Kabupaten Banyuwangi. Jurnal Istiqro, 5 (1), 53-71.

[2] Mallongi A. \& Natsir M.F., 2019, Efisiensi Pengolahan Limbah Cair Industri Tahu Menggunakan Biofilter Sistem Upflow dengan Penambahan Efektif Mikroorganisme 4. Jurnal Nasional Ilmu Kesehatan, 1 (2). 
[3] Sato A., Utomo P. \& Abineri H.S.B., 2015, Pengolahan Limbah Tahu Secara Anaerobik-Aerobik Kontinyu, Seminar Nasional Sains Dan Teknologi Terapan III. Institut Teknologi Adhi Tama Surabaya.

[4] Kusumawati I., Cahyanto M.N. \& Rahayu E.S., 2011, Modifikasi Pengolahan Limbah Cair Tahu di CV Kitagama Secara Anaerbik. Yogyakarta: Universitas Gadjah Mada.

[5] Farabi F., Pratama R., Maulana D. \& Fitriyano G., 2017, Pemanfaatan Limbah Padat Tahu Sebagai Bahan Baku Pembuatan Kertas. Prosiding Semnastek.

[6] Haryanto A.T., Dewi S.N. \& Riyadi J.S., 2020, Pemanfaatan Limbah Ampas Tahu Desa Ngasinan Etan, Gebang, Masaran, Sragen. Adi Widya: Jurnal Pengabdian Masyarakat, 4 (1).

[7] Rajagukguk K. 2020, Pengolahan Limbah Cair Tahu Menjadi Biogas Menggunakan Reaktor Biogas Portabel. Quantum Teknika: Jurnal Teknik Mesin Terapan, 1 (2).

[8] Sulistiyawati I., Rahayu N.L. \& Purwitaningrum F.S., 2020, Produksi Biolistrik Menggunakan Microbial Fuel Cell (MFC) Lactobacillus bulgaricus dengan Substrat Limbah Tempe dan Tahu. Majalah Ilmiah Biologi BIOSFERA: A Scientific Journal, 37 (2).

[9] Anggarini S., Hidayat N., Sunyoto N.M.S. \& Wulandari P.S., 2015, Optimization of Hydraulic Retention Time (Hrt) and Inoculums Addition In Wastewater Treatment Using Anaerobic Digestion System. Agriculture Agricultural Science Procedia, 3, 95-101.

[10] Chua J.-Y., Liu S.-Q.J. \& Technology, 2019, Soy Whey: More Than Just Wastewater from Tofu and Soy Protein Isolate Industry. Trends in Food Science, 91, 24-32.

[11] Lyberatos G. and Skiadas I., 1999, Modelling of Anaerobic Digestion-a Review. Global Nest Int $J, 1(2), 63-76$.

[12] Kurnianingsih R., Nurrijawati N., Pebdiani S.A., Suparman S., Fitriana N.Z., Ghazali M., Prasedya E.S., Astuti S.P. \& Sunarpi S., 2019, Pemanfaatan Limbah Cair Tahu Menjadi Produk Nata De Soya Berbasis Rumput Laut. Prosiding PEPADU, 1 (1), 303-7.

[13] Souisa G.M., Sidharta B. \& Pranata F.S., 2019, Pengaruh Acetobacter xylinum dan Ekstrak Kacang Hijau (Phaseolus radiatus L.) terhadap Produksi Nata dari Substrat Limbah Cair Tahu. Biota: Jurnal Ilmiah Ilmu-Ilmu Hayati, 11 (1), 27-33.

[14] Priyadi D.A. 2020, Kampung Tahu Gitik: Olahan Limbah Whey Tahu menjadi Nata De Soya dalam Pemberdayaan Masyarakat, Prosiding Seminar Nasional Rekarta 2020.

[15] Sarkono S., Muspiah A., Jupri A., Rohyani I.S. and Hadi I., 2018, Pemanfaatan Limbah Cair Pengolahan Tahu untuk Pembuatan Nata De Soya di Kelurahan Kekalik Jaya Kota Mataram. Prosiding Konferensi Nasional Pengabdian Kepada Masyarakat dan Corporate Social Responsibility, 1, 998-1005.

[16] Moertinah S. 2010, Kajian proses anaerobik sebagai alternatif teknologi pengolahan air limbah industri organik tinggi. Jurnal Riset Teknologi Pencegahan Pencemaran Industri, 1 (2), 104-14.

[17] Makiyah M., Sunarto W. and Prasetya A.T., 2015, Analisis Kadar NPK Pupuk Cair Limbah Tahu dengan Penambahan Tanaman Thitonia Diversivolia. Indonesian Journal Of Chemical Science, 4 (1).

[18] Desiana C., Banuwa I.S., Evizal R. and Yusnaini S., 2013, Pengaruh Pupuk Organik Cair Urin Sapi dan Limbah Tahu Terhadap Pertumbuhan Bibit Kakao (Theobroma cacao L.). Jurnal Agrotek Tropika, 1 (1).

[19] Al Amin A., Yulia A.E. and Nurbaiti N. 2017 Pemanfaatan Limbah Cair Tahu untuk Pertumbuhan dan Produksi Tanaman Pakcoy (Brassica rapa L.). Riau University.

[20] Mutmainah S., 2020, Pemanfaatan Air Limbah Tahu dengan Penambahan Sereh Wangi sebagai Pupuk Organik Cair. Masyarakat Berdaya dan Inovasi, 1 (2), 80-2. 
[21] Aliyenah A., Napoleon A.N.A. and Yudono B., 2015, Pemanfaatan Limbah Cair Industri Tahu sebagai Pupuk Cair Organik terhadap Pertumbuhan dan Produksi Tanaman Kangkung Darat (Ipomoea reptans Poir). Jurnal Penelitian Sains, 17 (3),

[22] Handayani T. and Niam H.M.A., 2018, Pemanfaatan Limbah Tahu sebagai Pupuk Cair Organik dan Es Krim untuk Meningkatkan Pendapatan dan Pengembangan Produk. Jurnal Dedikasi, 15.

[23] Etacheri V., Di Valentin C., Schneider J., Bahnemann D. and Pillai S.C., 2015, Visible-Light Activation of $\mathrm{TiO}_{2}$ Photocatalysts: Advances in Theory and Experiments. Journal of Photochemistry Photobiology C: Photochemistry Reviews, 25, 1-29.

[24] Tuhu Agung R. and Winata H.S., 2010, Pengolahan Air Limbah Industri Tahu dengan Menggunakan Teknologi Plasma. Jurnal Ilmiah Teknik Lingkungan, 2 (2), 19-28.

[25] Ali H., Hennawi H., Abdelzaher K., El-Halwagy A., Samir A. and Garamoon A., 2019, Evaluation of Synthesized Ozone by Dielectric Barrier Discharge Plasma for Degradation of Anionic Dyes from Their Solutions. Egyptian Journal of Chemistry, 62 (6), 1025-36.

[26] Huang F., Chen L., Wang H. and Yan Z., 2010, Analysis of the Degradation Mechanism of Methylene Blue by Atmospheric Pressure Dielectric Barrier Discharge Plasma. Chemical Engineering Journal, 162 (1), 250-6.

[27] Wang X.-Q., Wang F.-P., Chen W., Huang J., Bazaka K. and Ostrikov K.K., 2016, Nonequilibrium Plasma Prevention of Schistosoma japonicum Transmission. Scientific reports, 6, 35353. 